\title{
Assessing Accuracy of Vegetation Index Method to Estimate Actual Evapotranspiration
}

\author{
Arturo Reyes-González ${ }^{1, *}$, Jeppe Kjaersgaard ${ }^{2,3}$, Todd Trooien ${ }^{3}$, Christopher Hay ${ }^{4}$, \\ Laurent Ahiablame ${ }^{5}$ \\ ${ }^{1}$ Instituto Nacional de Investigaciones Forestales, Agricolas y Pecuarias (INIFAP), Mexico City, México \\ ${ }^{2}$ Minnesota Department of Agriculture, Saint Paul, USA \\ ${ }^{3}$ Department of Agricultural and Biosystems Engineering, South Dakota State University, Brookings, USA \\ ${ }^{4}$ Iowa Soybean Association, Ankeny, USA \\ ${ }^{5}$ University of California ANR, Oakland, USA \\ Email address: \\ reyes.arturo@inifap.gob.mx (A. Reyes-Gonzalez) \\ ${ }^{*}$ Corresponding author
}

\section{To cite this article:}

Arturo Reyes-González, Jeppe Kjaersgaard, Todd Trooien, Christopher Hay, Laurent Ahiablame. Assessing Accuracy of Vegetation Index Method to Estimate Actual Evapotranspiration. Earth Sciences. Vol. 7, No. 5, 2018, pp. 227-235. doi: 10.11648/j.earth.20180705.14

Received: August 15, 2018; Accepted: September 11, 2018; Published: October 11, 2018

\begin{abstract}
The estimation of actual crop evapotranspiration $\left(\mathrm{ET}_{\mathrm{a}}\right)$ maps using complex equations and remotely sensed shortwave and thermal infrared imagery can be challenging and may require input data that are not available. There is an opportunity, therefore to create a simpler and faster method to generate $\mathrm{ET}_{\mathrm{a}}$ maps using fewer input parameters for situations where limited input data is available or greater uncertainty in the resulting ET estimates are acceptable. We compared the estimates of $\mathrm{ET}_{\mathrm{a}}$ produced by a crop coefficient and NDVI-based $\left(\mathrm{K}_{\mathrm{c}-\mathrm{NDVI}}\right)$ method to a full energy balance (EB) method. Clear sky images from Landsat 7 and Landsat 8 were processed and used for the $\mathrm{ET}_{\mathrm{a}}$ estimations from maize during two growing seasons in eastern South Dakota, USA. The results showed that the $\mathrm{ET}_{\mathrm{a}}$ values from the $\mathrm{K}_{\mathrm{c}-\mathrm{NDVI}}$ method were lower than the $\mathrm{ET}_{\mathrm{a}}$ values from the EB method by $18 \%$ for 2015 and $11 \%$ for 2016 growing season. During study period the accuracy of $\mathrm{ET}_{\mathrm{a}}$ estimation decreased $17 \%$ with the $\mathrm{K}_{\mathrm{c}-\mathrm{NDVI}}$ method. For both years the mean bias error was $0.81 \mathrm{~mm}^{-1 a y^{-1}}$ and the root mean square error (RMSE) was $0.37 \mathrm{~mm} \mathrm{day}^{-1}$. The average daily $\mathrm{ET}_{\mathrm{a}}$ of $5.3 \mathrm{~mm} \mathrm{day}^{-1}$. The $\mathrm{K}_{\mathrm{c}-\mathrm{NDVI}}$ method performed acceptable for $\mathrm{ET}_{\mathrm{a}}$ estimations, indicating that this method can be used to estimate $\mathrm{ET}_{\mathrm{a}}$ with minimum input parameters at focused regional and field scales for short time periods.
\end{abstract}

Keywords: Actual Evapotranspiration, Surface Energy Balance, NDV Crop Coefficient

\section{Introduction}

The accurate estimation of crop evapotranspiration (ET) plays an essential role in irrigation water management such as in system planning and design, and irrigation scheduling [1]. ET varies relative to weather conditions including air temperature, solar radiation, wind speed, and air vapor pressure deficit and plant and soil conditions [2-4].

In irrigated agriculture a widely recommended method for estimating crop water needs or actual evapotranspiration $\left(E_{\mathrm{a}}\right)$ is multiplying reference evapotranspiration $\left(\mathrm{ET}_{\mathrm{r}}\right)$ with a crop coefficient $\left(\mathrm{K}_{\mathrm{c}}\right)[3,5,6]$ (Eq. 1).

$$
E T_{a}=E T_{r} \times K_{c}
$$

$\mathrm{ET}_{\mathrm{r}}$ is estimated based on meteorological information from a local weather station using the Penman-Monteith equation $[3,6]$. Generalized values of $\mathrm{K}_{\mathrm{c}}$ can be taken from literature values $[3,7]$ when appropriate. As an alternative to using $K_{c}$ values from the literature, there are several methods for measuring $\mathrm{ET}_{\mathrm{a}}$ directly to estimate $\mathrm{K}_{\mathrm{c}}$ values over homogeneous surfaces. Methods include weighing lysimeters, Bowen Ratio Energy Balance System (BREBS), Eddy Covariance (EC), scintillometers [8,9] or soil water balance methods. However, these methods provide point or near point measurements that may not fully represent the $\mathrm{ET}_{\mathrm{a}}$ 
from a larger population of fields other than where the measurement was conducted $[10,11]$. To overcome this problem of estimating $\mathrm{ET}_{\mathrm{a}}$ from a large number of fields, remote sensing-based ET estimation methods are increasingly used for estimating crop water use and $\mathrm{K}_{\mathrm{c}}$ values. A primary advantage of remote sensing-based methods is they provide $\mathrm{ET}_{\mathrm{a}}$ estimates at the same resolution of the satellite imagery, which enables the estimation of ET at a field-by-field or subfield basis at a regional scale [1214].

Several models based on remote sensing techniques have been developed to estimate $\mathrm{ET}_{\mathrm{a}}$ at different scales [8]. Mapping EvapoTranspiration at High Resolution using Internalized Calibration (METRIC) Model [13, 15, 16] is one such model. METRIC utilizes shortwave and thermal wavebands along with ground-based weather information to solve the surface energy balance to estimate the $\mathrm{K}_{\mathrm{c}}$ through a series of steps, which includes estimates of the dominant atmospheric heat transport mechanisms. In the last decade the METRIC model has been used to estimate $\mathrm{ET}_{\mathrm{a}}$ at field and regional scales in different crops and vegetation types including cotton [17, 18], wheat [10, 19], banana orchard [20], soybean [21], maize [22], cover crops [23], alfalfa [24], pistacho [25], vineyard [26, 27], olive orchard [28], sugarcane [29], and forest in the Amazon [30].

Another, simpler method using satellite imagery is using the Normalized Difference Vegetation Index (NDVI) to estimate $K_{c}[31,32]$ for $\mathrm{ET}_{\mathrm{a}}$ estimation using Eq. 1. NDVI indicates the density and robustness of surface vegetation [33] and reflects the actual crop conditions [32, 34]. For well watered crops there is typically a linear, crop-specific correlation between NDVI and $\mathrm{K}_{\mathrm{c}}$. For more than 30 years local regression functions for the NDVI and $\mathrm{K}_{\mathrm{c}}$ relationship have been established for agricultural crops (e.g. [16, 3449]).

We used two satellite-based approaches to estimate $\mathrm{ET}_{\mathrm{a}}$ for irrigation applications namely 1) the energy balance method using METRIC and 2) the $\mathrm{K}_{\mathrm{c}}$ vs NDVI method [9, 50-52]. The energy balance method (EB method) is complex, computational involved and data intensive and require trained personnel to complete. In contrast, the $\mathrm{K}_{\mathrm{c}}$ vs NDVI method, which will be referred to as $\mathrm{K}_{\mathrm{c}-\mathrm{NDVI}}$ method henceforth, is simpler, less data intensive and can be completed within a shorter timeframe, and at the same spatial resolution as the energy balance [9, 33, 51, 53]. The performance and a comparison between these methods for $\mathrm{ET}_{\mathrm{a}}$ estimation have not been clearly determined in eastern South Dakota. The objective of this study was to compare the accuracy of the $\mathrm{K}_{\mathrm{c}-\mathrm{NDVI}}$ method to calculate $\mathrm{ET}_{\mathrm{a}}$ relative to the EB method calculated by the METRIC model over two growing seasons in eastern South Dakota.

\section{Materials and Methods}

\subsection{Study Area}

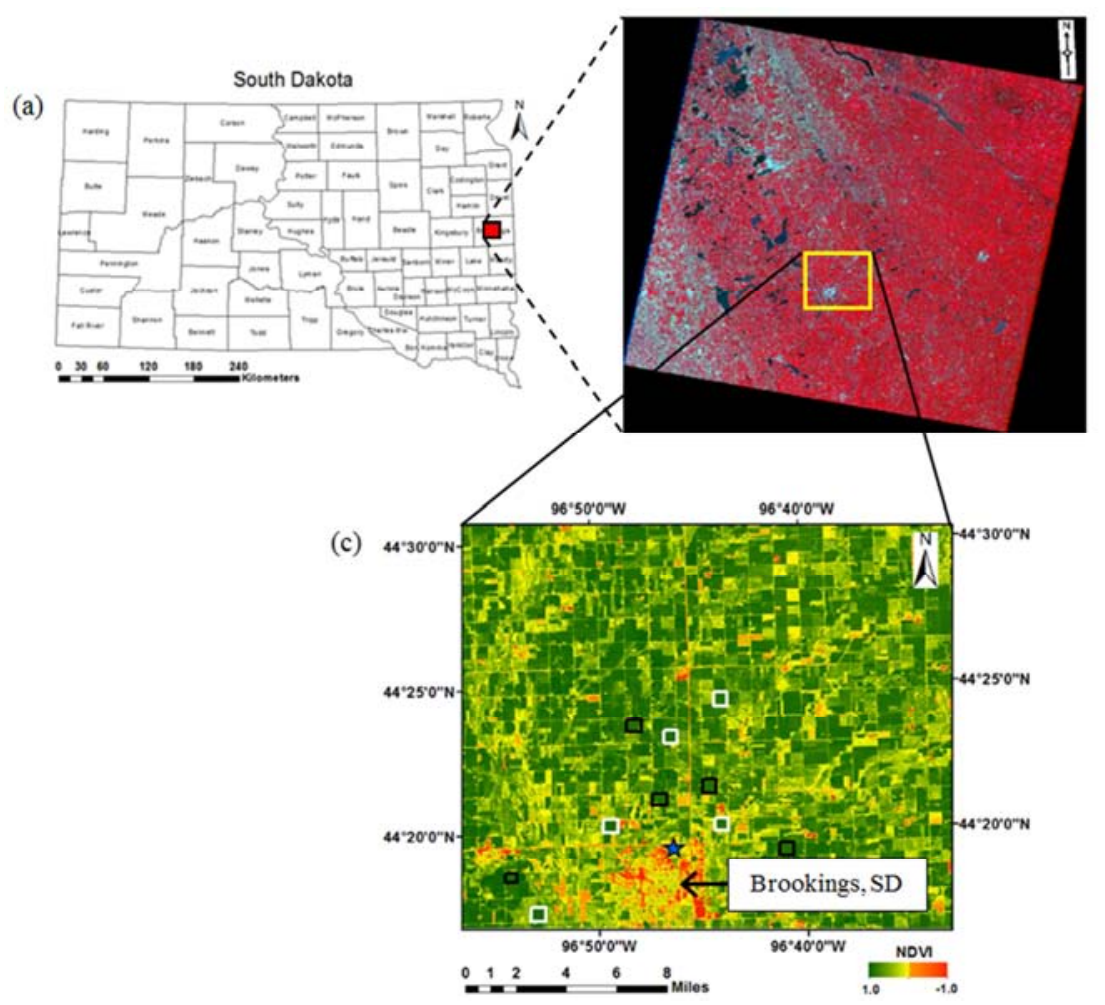

Figure 1. Map of the state of South Dakota and counties with the red rectangle showing the study area (a), Landsat image with the yellow rectangle indicating the area of study near the city of Brookings (b), and map of NDVI estimated from Landsat on July 18, 2015. The white and black rectangles indicate maize fields selected in 2015 and 2016, respectively and the blue star showing the weather station location (c). 
The study was carried out in eastern South Dakota during the 2015 and 2016 growing seasons (Figure 1 (a)). The study area had an average latitude of $44^{\circ} 19^{\prime} \mathrm{N}$ and longitude of $96^{\circ} 46^{\prime} \mathrm{W}$ and elevation of $500 \mathrm{~m}$ above sea level (Figure 1 (b)). Five maize fields located within $15 \mathrm{~km}$ of each other were studied each year. Different fields were used the two years due to the crop rotation (Figure 1 (c)). All fields were in a maize - soybean crop rotation system common to the region. Weather information was acquired from the Brookings Mesonet weather station operated by the South Dakota Climate Office in each growing season. The soils were silty clay loam with $0-2 \%$ slope (NRCS Web Soil Survey 2016). The actual maize plant population density was approximately 78,000 plants $\mathrm{ha}^{-1}$ and the fields were managed using common agricultural practices used in the region. The crop was not considered subjects to growthlimiting stress from pests, weed or nutrient deficiencies.
The maize fields were around 64 hectares in size. Irrigation is uncommon in this area and none fields were irrigated. The normal average annual precipitation is $533 \mathrm{~mm}$, of which $3 / 4$ typically falls during the growing season (AprilOctober).

\subsection{Landsat Images}

Clear sky images were used for the $\mathrm{ET}_{\mathrm{a}}$ estimations (Table 1). The images were downloaded from the United States Geological Survey (USGS) EROS Datacenter and processed using the METRIC model running in the ERDAS Imagine software environment [54]. The wedge-shaped gaps appearing within the Landsat 7 images as result of the SLCoff issue were removed using the Imagine built-in focal analysis tool [55].

Table 1. The year, acquisition dates, Landsat satellite platform, path/row and image overpass time for the imagery used for the ET $T_{\text {a }}$ estimations.

\begin{tabular}{|c|c|c|c|c|}
\hline Year & Acquisition Dates & Satellite & Path/Row & Overpass time (local) \\
\hline \multirow[t]{6}{*}{2015} & 8-Jun-17 & Landsat 7 & $29 / 29$ & $11: 10: 58$ AM \\
\hline & 10-Jul-15 & Landsat 7 & $29 / 29$ & 11:11:06 AM \\
\hline & 18-Jul-15 & Landsat 8 & $29 / 29$ & $11: 10: 57$ AM \\
\hline & 3-Aug-15 & Landsat 8 & $29 / 29$ & 11:11:00 AM \\
\hline & 12-Sep-15 & Landsat 7 & $29 / 29$ & 11:11:18 AM \\
\hline & 20-Sep-15 & Landsat 8 & $29 / 29$ & $11: 11: 21 \mathrm{AM}$ \\
\hline \multirow[t]{7}{*}{2016} & 2-Jun-16 & Landsat 8 & $29 / 29$ & 11:11:03 AM \\
\hline & 26-Jun-16 & Landsat 7 & $29 / 29$ & $11: 13: 56$ AM \\
\hline & 12-Jul-16 & Landsat 7 & $29 / 29$ & $11: 13: 55$ AM \\
\hline & 20-Jul-16 & Landsat 8 & $29 / 29$ & 11:11:21 AM \\
\hline & 5-Aug-16 & Landsat 8 & $29 / 29$ & $11: 11: 24 \mathrm{AM}$ \\
\hline & 21-Aug-16 & Landsat 8 & $29 / 29$ & 11:11:30 AM \\
\hline & 14-Sep-16 & Landsat 7 & $29 / 29$ & 11:14:05 AM \\
\hline
\end{tabular}

\subsection{Pixel Selection}

Ten pixels in each field were randomly selected and their values for NDVI, $\mathrm{K}_{\mathrm{c}}$ and $\mathrm{ET}_{\mathrm{a}}$ were extracted. The same pixels were used throughout each growing season. The number of pixels (10) were assumed to be representative of each entire maize field.

\subsection{METRIC Model and Input Parameters}

METRIC model version 3.0 was used to estimate $\mathrm{ET}_{\mathrm{a}}$. Please see $[13,15,56]$ for a detailed discussion of the model calculations.

In the METRIC model four primary input parameters are used to estimate $\mathrm{ET}_{\mathrm{a}}$ namely the Landsat image (including shortwave and thermal bands), digital elevation map, land cover map, and weather data (Figure 2). The elevation and land cover map were reprojected in meters to the same pixel size as the Landsat images $(30 \mathrm{~m} \times 30 \mathrm{~m})$.

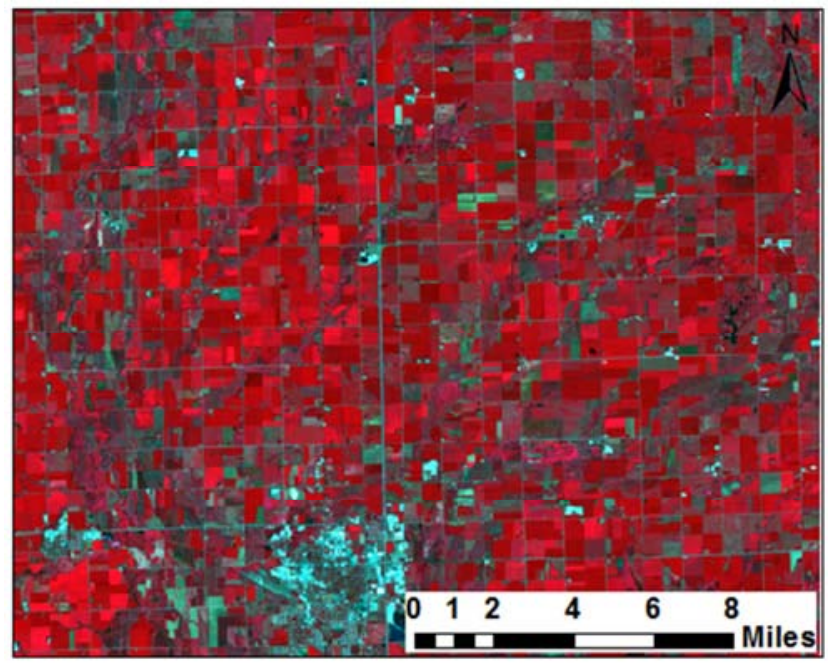

(a) 


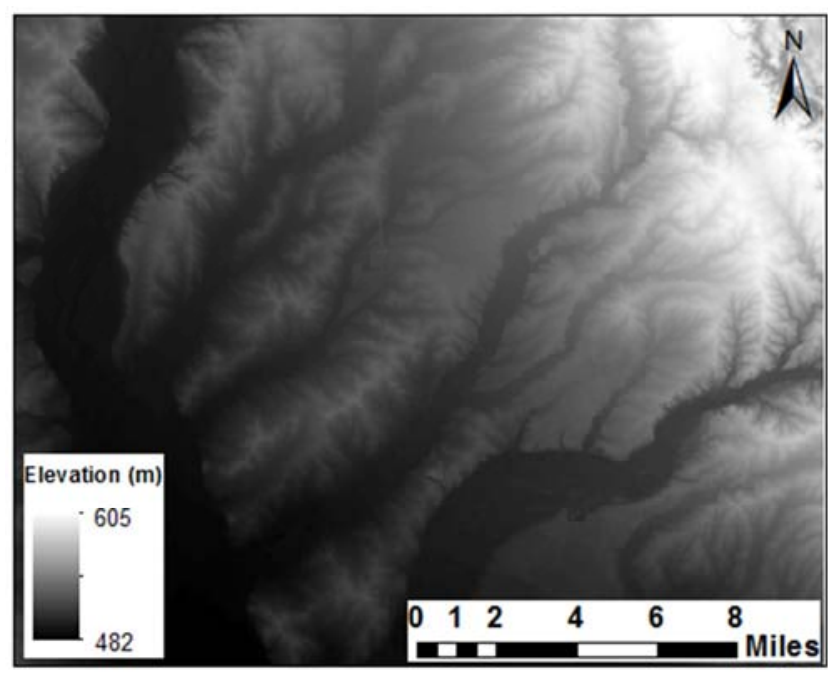

(b)

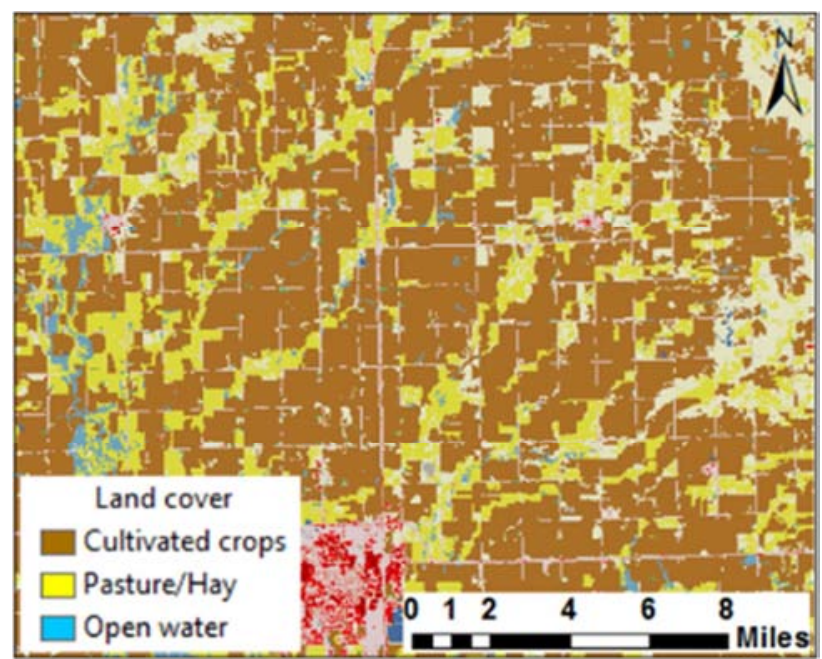

(c)

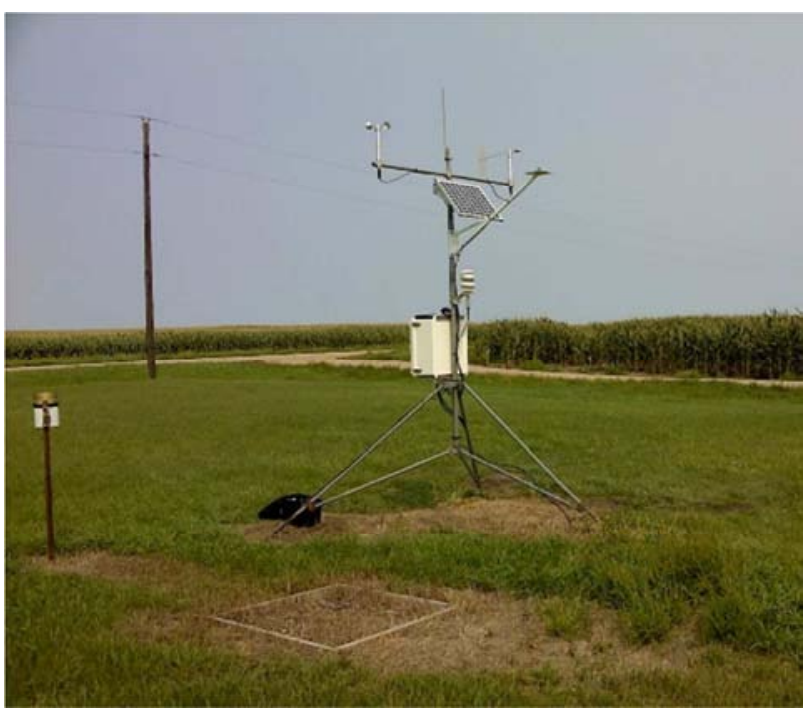

(d)

Figure 2. Examples of the input information needed for the $E T_{a}$ estimation using METRIC, Landsat image here shown in false color (a), elevation map (b), land cover map (c), and weather data (d).

\subsection{NDVI Calculations}

The NDVI values range from -1.0 to +1.0 , with water having negative values and dense vegetation having high positive values $[57,58]$.

For Landsat 7 NDVI was calculated as:

$$
N D V I=\frac{\left(N I R_{\text {band } 4}-\text { Red }_{\text {band } 3}\right)}{\left(N I R_{\text {band } 4}+\text { Red }_{\text {band } 3}\right)}
$$

For Landsat 8 NDVI was calculated as:

$$
N D V I=\frac{\left(\operatorname{NIR}_{\text {band } 5}-\text { Red }_{\text {band } 4}\right)}{\left(\text { NIR }_{\text {band } 5}+\text { Red }_{\text {band } 4}\right)}
$$

where $N I R_{\text {band }}$ and $R e d_{\text {band }}$ are the corrected spectral radiance in the near-infrared and red bands, respectively.

\subsection{Crop Coefficient (K) Curves for NDVI Based Method}

The alfalfa-based $\mathrm{K}_{\mathrm{c}}$ values from [7] for 2015 and 2016 crop growing seasons were used. For $\mathrm{K}_{\mathrm{c}}$ estimations this method divides the growing season into two periods, viz. percent of time from planting to effective cover and days after effective cover to harvest. The effective cover of maize for our study occurred in middle of July for 2015 and early July for 2016 based on field observations of the crop phenology.

\subsection{Relationship Between NDVI and $K_{c}$ and Generation of ET $\boldsymbol{T}_{a}$ maps}

A relationship between NDVI derived from NDVI maps and $\mathrm{K}_{\mathrm{c}}$ values from [7] at each overpass date was established. This relationship was used to develop a linear regression equation for both seasons. Those linear regression equations were used to generate $\mathrm{K}_{\mathrm{c}}$ maps using Model Maker tool of ERDAS Imagine. The $\mathrm{K}_{\mathrm{c}}$ values derived from the $\mathrm{K}_{\mathrm{c}}$ maps were multiplied by $\mathrm{ET}_{\mathrm{r}}$ to create $\mathrm{ET}_{\mathrm{a}}$ maps for both seasons using the $\mathrm{K}_{\mathrm{c}-\mathrm{NDVI}}$ method. The $\mathrm{ET}_{\mathrm{r}}$ values were estimated based on weather data from the automatic Brookings weather station. In the final step, the $\mathrm{ET}_{\mathrm{a}}$ values from $\mathrm{ET}_{\mathrm{a}}$ maps were compared with $\mathrm{ET}_{\mathrm{a}}$ values obtained from the $\mathrm{EB}$ method for each overpass date and for each growing season.

\subsection{Average Ratio of ET $T_{a} K_{c-N V I}$ to $E T_{a} E B$ and Their Relationship}

The average ratio of $\mathrm{ET}_{\mathrm{a}} \mathrm{K}_{\mathrm{c}-\mathrm{NDVI}}$ to $\mathrm{ET}_{\mathrm{a}} \mathrm{EB}$ was calculated to quantify the accuracy and performance of the $\mathrm{K}_{\mathrm{c}-\mathrm{NDVI}}$ method for $\mathrm{ET}_{\mathrm{a}}$ estimations.

\section{Results and Discussion}

\subsection{ET $T_{a}$ Maps and Daily Spatial Distribution of ET Comparison}

Figure 3 shows an example of $\mathrm{ET}_{\mathrm{a}}$ maps developed using the EB method and developed by $\mathrm{K}_{\mathrm{c}-\mathrm{NDVI}}$ method on July 20, 2016. The $\mathrm{ET}_{\mathrm{a}} \mathrm{K}_{\mathrm{c}-\mathrm{NDVI}}$ method map generally shows higher $\mathrm{ET}_{\mathrm{a}}$ values compared to the $\mathrm{ET}_{\mathrm{a}} \mathrm{EB}$ method. This is due to the calibration of the maps and to a lesser degree differences 
in resolution between the maps. Also there is a difference in how the colors are displayed between these two maps. The pixel resolution in the $\mathrm{ET}_{\mathrm{a}} \mathrm{K}_{\mathrm{c}-\mathrm{NDVI}}$ method is 30 by $30 \mathrm{~m}$,

\section{ETaEB method}

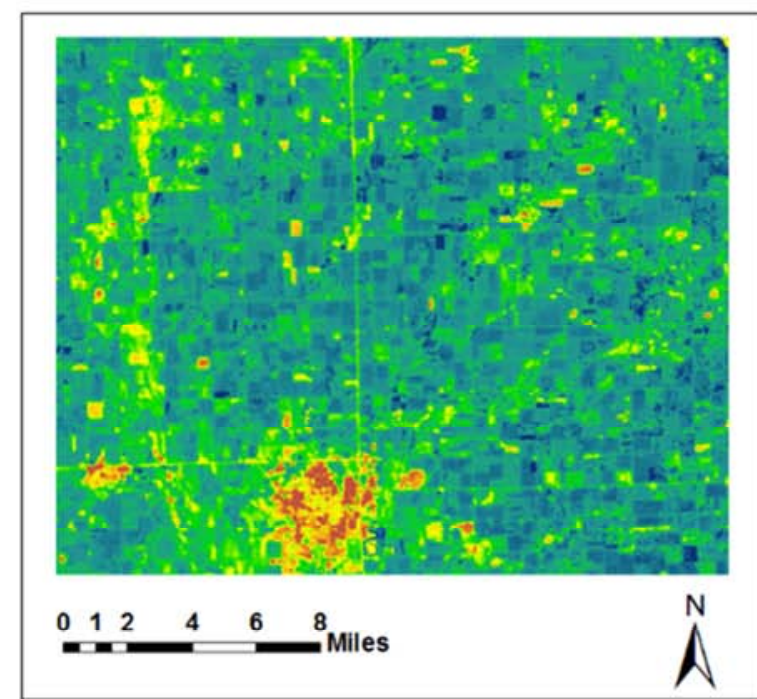

while in $\mathrm{ET}_{\mathrm{a}} \mathrm{EB}$ method the thermal pixel resolution for Landsat 7 is 60 by $60 \mathrm{~m}$ and for Landsat 8 is 100 by $100 \mathrm{~m}$.

\section{ETa $K_{c-N D v i}$ method}

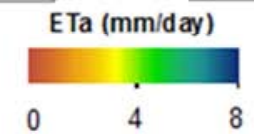

Figure 3. ET a maps generated using the EB method (left) and using the $K_{c-N D V}$ method (right) on July 20, 2016.

A similar comparison of $\mathrm{ET}_{\mathrm{a}}$ maps over agricultural areas generated by the METRIC model using energy balance and using vegetation index data were reported by Allen et al. [13] and Anderson et al. [59] in Twin Falls, Idaho. Mokhtari et al. [25], found that the METRIC-based ET is highly sensitive to surface temperature, but less sensitive to NDVI.

For the 2015 season, Figure 4 shows that the discrepancy between the $\mathrm{ET}_{\mathrm{a}}$ values were higher at the beginning and at the end of the growing season. The highest $\mathrm{ET}_{\mathrm{a}}$ values were showed in the mid-season (July 18) 7.9 and $7.7 \mathrm{~mm} \mathrm{day}^{-1}$ for the EB method and the $\mathrm{K}_{\mathrm{c}-\mathrm{NDVI}}$ method, respectively.

For the 2016 season, Figure 4 shows low $\mathrm{ET}_{\mathrm{a}}$ values at the beginning of the growing season at 2.8 and $1.7 \mathrm{~mm} \mathrm{day}^{-1}$ for $\mathrm{EB}$ method and for $\mathrm{K}_{\mathrm{c}-\mathrm{NDVI}}$ method, respectively. Moderate $\mathrm{ET}_{\mathrm{a}}$ presented at the end of the season for EB method was 4.2 $\mathrm{mm}$ day $^{-1}$ and for $\mathrm{K}_{\mathrm{c}-\mathrm{NDVI}}$ method was $3.0 \mathrm{~mm}$ day $^{-1}$. High $\mathrm{ET}_{\mathrm{a}}$ values were observed in the mid-season (July 12) with $8.9 \mathrm{~mm} \mathrm{day}^{-1}$ for $\mathrm{EB}$ method and $8.7 \mathrm{~mm}^{\text {day }}{ }^{-1}$ for $\mathrm{K}_{\mathrm{c}-\mathrm{NDVI}}$ method.

In general, the $\mathrm{ET}_{\mathrm{a}}$ values estimated with $\mathrm{EB}$ method were higher than the $\mathrm{ET}_{\mathrm{a}}$ values estimated with $\mathrm{K}_{\mathrm{c}-\mathrm{NDVI}}$ method by 18 and $11 \%$ for 2015 and 2016 growing seasons, respectively. Because the $\mathrm{K}_{\mathrm{c}-\mathrm{NDVI}}$ method overwhelmingly considers transpiration from green vegetation, and only to a small extent evaporation from bare soil, some underestimation during the shoulder periods of the growing season is common. These results coincide with those in previous studies reported by Anderson et al. [59] who reported that $\mathrm{ET}_{\mathrm{a}}$ calculated from vegetation index data always were found to underestimate seasonal $\mathrm{ET}_{\mathrm{a}}$ values in irrigated areas in Idaho.

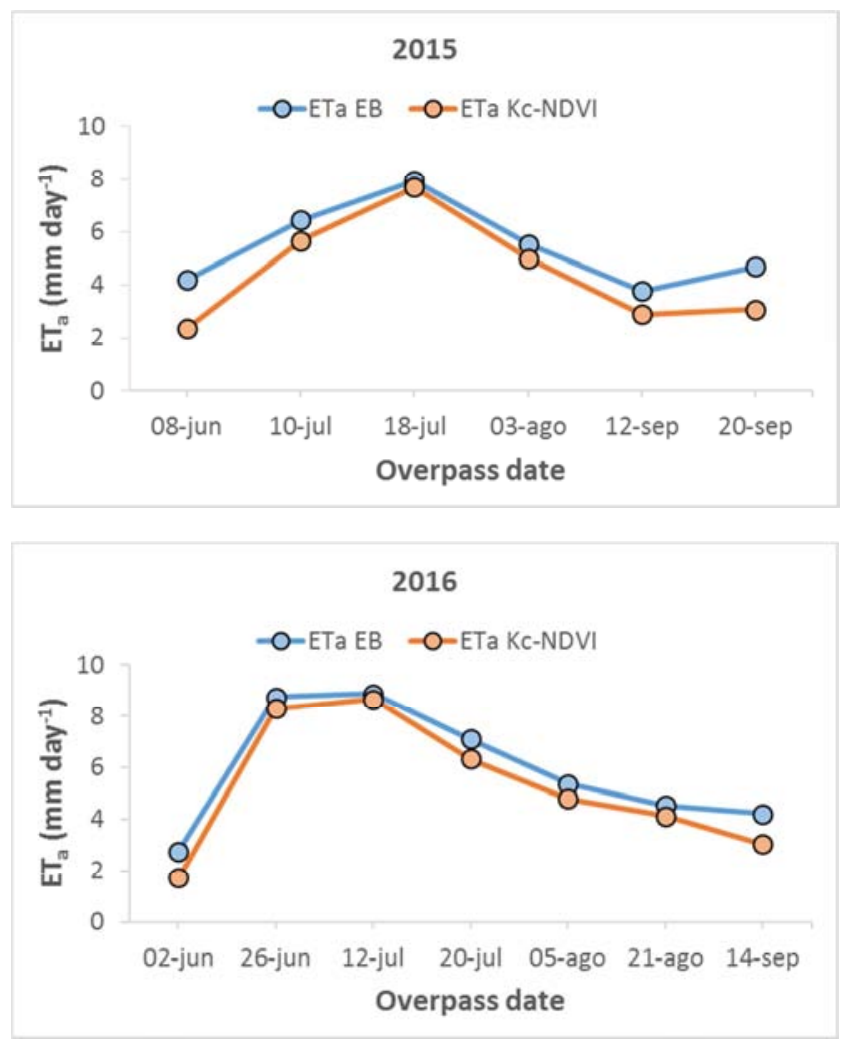

Figure 4. $E T_{a} E B$ and $E T_{a} K_{c-N D V I}$ values comparisons throughout the 2015 and 2016 growing seasons. 


\subsection{Average Ratio of ET $T_{a} K_{c-N D V I}$ Method to ET $E B$ Method}

The average ratio distribution of $\mathrm{ET}_{\mathrm{a}} \mathrm{K}_{\mathrm{c}-\mathrm{NDVI}}$ to $\mathrm{ET}_{\mathrm{a}} \mathrm{EB}$ method for 2015 and 2016 crop growing seasons are shown in Figure 5. This figure shows that all average ratios are below 1 , which is denoted by the thick blue line. This means that the $\mathrm{ET}_{\mathrm{a}} \mathrm{K}_{\mathrm{c}-\mathrm{NDVI}}$ values were lower than the $\mathrm{ET}_{\mathrm{a}} \mathrm{EB}$ values during the two growing seasons. In early and late season the $\mathrm{K}_{\mathrm{c}-\mathrm{NDVI}}$ method showed the far values from 1 , while in the mid-season the values were close to 1 . Indicating that $\mathrm{K}_{\mathrm{c}-\mathrm{NDVI}}$ is more accurate for $\mathrm{ET}_{\mathrm{a}}$ estimations during the mid-season than early and late seasons, this reflects low vegetation cover, high soil evaporation, and leaf senescence $[13,16,44,59]$. Therefore, the $\mathrm{K}_{\mathrm{c}-\mathrm{NDVI}}$ method gives less accurate estimation of $\mathrm{ET}_{\mathrm{a}}$ during early and late season periods. For irrigation scheduling purposes during periods with high crop water demand at the middle of the growing season, the $\mathrm{K}_{\mathrm{c}-\mathrm{NDVI}}$ method may be acceptable. However, $\mathrm{ET}_{\mathrm{a}}$ values from $\mathrm{K}_{\mathrm{c}-\mathrm{NDVI}}$ method need to be adjusted during early and during late season to get close or accurate estimates to $\mathrm{ET}_{\mathrm{a}} \mathrm{EB}$ values. The adjustment factor $\left(\mathrm{ET}_{\mathrm{a}} \mathrm{K}_{\mathrm{c}-\mathrm{NDVI}} / 0.66=\right.$ $\left.\mathrm{ET}_{\mathrm{a}} \mathrm{EB}\right)$ for the 2015 growing season was 0.66 and $\left(\mathrm{ET}_{\mathrm{a}} \mathrm{K}_{\mathrm{c}-}\right.$ NDVI $/ 0.71=\mathrm{ET}_{\mathrm{a}} \mathrm{EB}$ ) for the 2016 growing season it was 0.71 .

For the entire 2015 growing season the underestimation was $21 \%$ and for the mid-season only (July-August) (excluding early and late season) was $12 \%$, while for entire 2016 growing season the percent of error was $13 \%$ and for the mid-season it was 7\%. The total average error for the two growing seasons was $17 \%$. This general percent of underestimation with the $\mathrm{K}_{\mathrm{c}-\mathrm{NDVI}}$ method is may be acceptable in some applications and are within the $10-30 \%$ error for an experienced expert reported by Allen et al. [9]. The average error for both growing seasons during the midseason stage was less than $10 \%$.

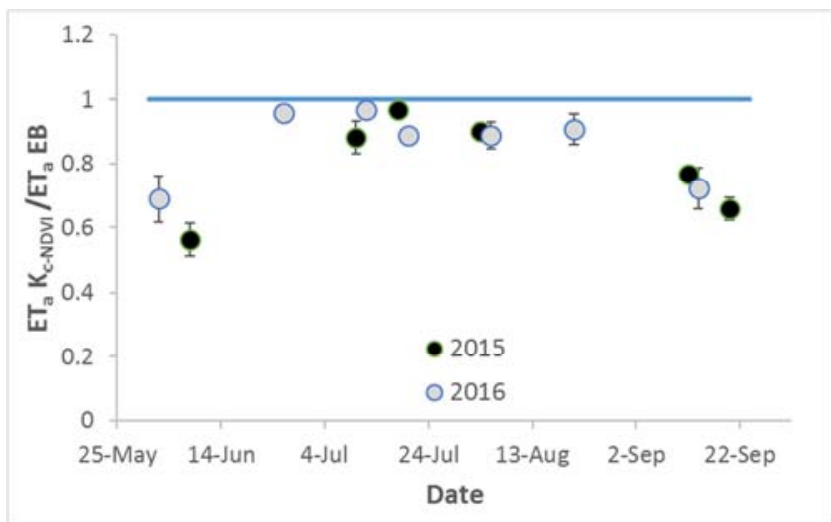

Figure 5. Average ratio of $E T_{a} K_{c-N D V I}$ to $E T_{a} E B$ for the 2015 and 2016 growing seasons. The thick blue line denotes 1 (or 100\%) agreement with $E T_{a} E B$ method. Bars show standard deviation of $E T_{a}$ values.

\subsection{Relationship Between ET $T_{a} E B$ Method and $E T_{a} K_{c-N D V I}$ Method}

An acceptable relationship was found between $\mathrm{ET}_{\mathrm{a}} \mathrm{EB}$ method and $\mathrm{ET}_{\mathrm{a}} \mathrm{K}_{\mathrm{c}-\mathrm{NDVI}}$ method during the 2015 and 2016 seasons with coefficient of determination $\left(\mathrm{r}^{2}\right)$ of 0.97 (Figure $6)$. The corresponding mean bias error was $0.81 \mathrm{~mm} \mathrm{day}^{-1}$ and the root mean square error (RMSE) was $0.37 \mathrm{~mm} \mathrm{day}^{-1}$. The average daily $\mathrm{ET}_{\mathrm{a}}$ was $5.3 \mathrm{~mm} \mathrm{day}^{-1}$.

In this study, the $\mathrm{K}_{\mathrm{c}-\mathrm{NDVI}}$ method performed acceptably for $\mathrm{ET}_{\mathrm{a}}$ estimations during the two growing seasons. This indicates the $\mathrm{K}_{\mathrm{c}-\mathrm{NDVI}}$ method can be used to estimate crop water requirements at regional and field scale in regions where digital elevation, land cover map and thermal infrared data are not available and where higher uncertainty is acceptable.

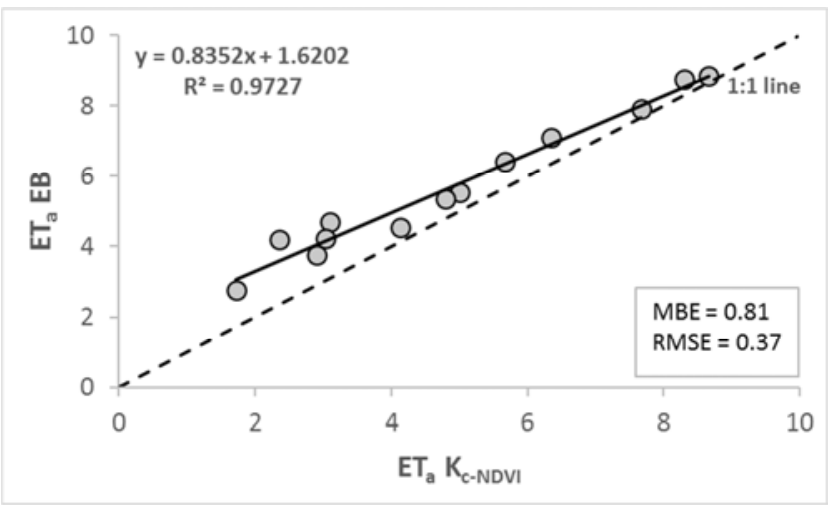

Figure 6. Relationship between $E T_{a} E B$ method and $E T_{a} K_{c-N D V I}$ method for maize during two growing seasons in eastern South Dakota. The black dashed line indicates the 1:1 line.

\section{Conclusions}

$\mathrm{ET}_{\mathrm{a}}$ values calculated with $\mathrm{K}_{\mathrm{c}-\mathrm{NDVI}}$ method were lower than the $\mathrm{ET}_{\mathrm{a}}$ values calculated with EB method by 18 and $11 \%$ for the 2015 and 2016 growing season, respectively. The $\mathrm{ET}_{\mathrm{a}} \mathrm{K}_{\mathrm{c}-}$ NDVI values were less than the $\mathrm{ET}_{\mathrm{a}} \mathrm{EB}$ values during the two seasons especially at the beginning and at the end of the seasons when the vegetation cover was incomplete. Soil evaporation is not fully captured by the $\mathrm{K}_{\mathrm{c}-\mathrm{NDVI}}$ method. As a result, the $\mathrm{ET}_{\mathrm{a}}$ estimated using the $\mathrm{K}_{\mathrm{c}-\mathrm{NDVI}}$ method underestimated the values by $17 \%$ compared to the EB method during the period of study. The $\mathrm{K}_{\mathrm{c}-\mathrm{NDVI}}$ method is less accurate during the early and late portion of the growing season, however for irrigation scheduling purposes, this method may be acceptable.

The results showed a good relationship between EB method and the $\mathrm{K}_{\mathrm{c}-\mathrm{NDVI}}$ method for $\mathrm{ET}_{\mathrm{a}}$ estimation throughout two growing seasons. The $\mathrm{K}_{\mathrm{c}-\mathrm{NDVI}}$ method can be a reliable method to calculate $\mathrm{ET}_{\mathrm{a}}$ using minimum input parameters.

\section{Acknowledgements}

The first author would like to thank the National Council for Science and Technology of México (CONACYT) and the National Institute of Forestry, Agriculture, and Livestock Research (INIFAP) for funding his doctoral scholarship. Additional funding was provided by the South Dakota Agricultural Experiment Station, South Dakota Water Resources Institute, and the South Dakota Corn Utilization Council. 


\section{References}

[1] Garatuza-Payan, J., \& Watts, C. J. (2005). The use of remote sensing for estimating ET of irrigated wheat and cotton in Northwest Mexico. Irrigation and Drainage Systems, 19(3), 301. doi:10.1007/s10795-005-5192-2.

[2] Hanson, R. L. (1991). Evapotranspiration and Droughts. In: Paulson RW, Chase EB, Roberts RS, Moody DW, Compilers, National Water Summary 1988-89-hydrologic events and floods and droughts: U.S. Geological Survey Water Supply (2375), 99-104.

[3] Allen, R. G., Pereira, L. S., Raes, D., \& Smith, M. (1998). Crop evapotranspiration-Guidelines for computing crop water requirements-FAO Irrigation and drainage paper 56. FAO, Rome, 300(9), D05109.

[4] George, B. A., Reddy, B., Raghuwanshi, N., \& Wallender, W. (2002). Decision support system for estimating reference evapotranspiration. Journal of Irrigation and Drainage Engineering, 128(1), 1-10.

[5] Jensen, M. E., Burman, R. D., \& Allen, R. G. (1990). Evapotranspiration and irrigation water requirements, ASCE Manuals and Reports on Engineering Practice No. 70, 332pp.

[6] ASCE-EWRI. (2005). The ASCE standardized reference evapotranspiration equation; ASCE-EWRI Standardization of Reference Evapotranspiration Task Committee Report; ASCE: Reston, VA, USA.

[7] Jensen, M. E., \& Allen, R. G. (2016). Evaporation, Evapotranspiration, and Irrigation Water Requirements. ASCE Manuals and Reports on Engineering Practice No. 70, $744 p p$.

[8] Gowda, P. H., Chavez, J. L., Colaizzi, P. D., Evett, S. R., Howell, T. A., \& Tolk, J. A. (2008). ET mapping for agricultural water management: present status and challenges. Irrigation Science, 26(3), 223-237.

[9] Allen, R. G., Pereira, L. S., Howell, T. A., \& Jensen, M. E. (2011b). Evapotranspiration information reporting: I. Factors governing measurement accuracy. Agricultural Water Management, 98(6), 899-920.

[10] Santos, C., Lorite, I., Tasumi, M., Allen, R., \& Fereres, E. (2008). Integrating satellite-based evapotranspiration with simulation models for irrigation management at the scheme level. Irrigation Science, 26(3), 277-288.

[11] Irmak, A., Ratcliffe, I., Ranade, P., Hubbard, K. G., Singh, R. K., Kamble, B., \& Kjaersgaard, J. (2011). Estimation of land surface evapotranspiration with a satellite remote sensing procedure. Great plains research, 73-88.

[12] Allen, R. G., Tasumi, M., Morse, A., Trezza, R., Wright, J. L., Bastiaanssen, W., Robison, C. W. (2007b). Satellite-based energy balance for mapping evapotranspiration with internalized calibration (METRIC) - Applications. Journal of Irrigation and Drainage Engineering, 133(4), 395-406.

[13] Allen, R., Irmak, A., Trezza, R., Hendrickx, J. M., Bastiaanssen, W., \& Kjaersgaard, J. (2011a). Satellite-based ET estimation in agriculture using SEBAL and METRIC. Hydrological Processes, 25(26), 4011-4027.
[14] Kjaersgaard, J., Allen, R., \& Irmak, A. (2011). Improved methods for estimating monthly and growing season ET using METRIC applied to moderate resolution satellite imagery. Hydrological Processes, 25(26), 4028-4036.

[15] Allen, R. G., Tasumi, M., \& Trezza, R. (2007a). Satellitebased energy balance for mapping evapotranspiration with internalized calibration (METRIC)-Model. Journal of Irrigation and Drainage Engineering, 133(4), 380-394.

[16] Tasumi, M., Allen, R. G., Trezza, R., \& Wright, J. L. (2005). Satellite-based energy balance to assess within-population variance of crop coefficient curves. Journal of Irrigation and Drainage Engineering, 131(1), 94-109.

[17] Chavez, J. L., Gowda, P. H., Howell, T. A., Marek, T. H., \& New, L. L. (2007). Evapotranspiration mapping using METRICTM for a region with highly advective conditions. Paper presented at the 2007 ASABE Annual International Meeting, Technical Papers.

[18] French, A. N., Hunsaker, D. J., \& Thorp, K. R. (2015). Remote sensing of evapotranspiration over cotton using the TSEB and METRIC energy balance models. Remote Sensing of Environment, 158, 281-294.

[19] Droogers, P., Immerzeel, W., \& Lorite, I. (2010). Estimating actual irrigation application by remotely sensed evapotranspiration observations. Agricultural Water Management, 97(9), 1351-1359.

[20] Folhes, M. T., Rennó, C. D., \& Soares, J. V. (2009). Remote sensing for irrigation water management in the semi-arid Northeast of Brazil. Agricultural Water Management, 96(10), 1398-1408.

[21] Choi, M., Kustas, W. P., Anderson, M. C., Allen, R. G., Li, F., \& Kjaersgaard, J. H. (2009). An intercomparison of three remote sensing-based surface energy balance algorithms over a corn and soybean production region (Iowa, US) during SMACEX. Agricultural and Forest Meteorology, 149(12), 2082-2097.

[22] Singh, R. K., \& Irmak, A. (2009). Estimation of crop coefficients using satellite remote sensing. Journal of Irrigation and Drainage Engineering, 135(5), 597-608.

[23] Hankerson, B., Kjaersgaard, J., \& Hay, C. (2012). Estimation of evapotranspiration from fields with and without cover crops using remote sensing and in situ methods. Remote Sensing, 4(12), 3796-3812.

[24] Mkhwanazi, M., \& Chávez, J. L. (2012). Using METRIC to estimate surface energy fluxes over an alfalfa field in Eastern Colorado. Hydrology Days, Colorado State University USA (Accessed on August 26th 2014 from: http:// hydrologydays. colostate.edu/Papers_2012/Mcebisi_paper.pdf).

[25] Mokhtari, M., Ahmad, B., Hoveidi, H., \& Busu, I. (2013). Sensitivity analysis of METRIC-based evapotranspiration algorithm. International Journal of Environmental Research, $7(2), 407-422$.

[26] Carrasco-Benavides, M., Ortega-Farías, S., Lagos, L. O., Kleissl, J., Morales-Salinas, L., \& Kilic, A. (2014). Parameterization of the Satellite-Based Model (METRIC) for the estimation of instantaneous surface energy balance components over a drip-irrigated vineyard. Remote Sensing, 6(11), 11342-11371. 
[27] Gordillo Salinas, V. M., Flores Magdaleno, H., Tijerina Chávez, L., \& Arteaga Ramírez, R. (2014). Estimación de la evapotranspiración utilizando un balance de energía e imágenes satelitales. Revista mexicana de ciencias agrícolas, 5(1), 143-155.

[28] Paço, T. A., Pôças, I., Cunha, M., Silvestre, J. C., Santos, F. L., Paredes, P., \& Pereira, L. S. (2014). Evapotranspiration and crop coefficients for a super intensive olive orchard. An application of SIMDualKc and METRIC models using ground and satellite observations. Journal of Hydrology, 519, 20672080 .

[29] Zhang, H., Anderson, R. G., \& Wang, D. (2015). Satellitebased crop coefficient and regional water use estimates for Hawaiian sugarcane. Field Crops Research, 180, 143-154.

[30] Numata, I., Khand, K., Kjaersgaard, J., Cochrane, M. A., \& Silva, S. S. (2017). Evaluation of Landsat-Based METRIC Modeling to Provide High-Spatial Resolution Evapotranspiration Estimates for Amazonian Forests. Remote Sensing, 9(1), 46.

[31] Rouse Jr, J. W., Haas, R., Schell, J., \& Deering, D. (1974). Monitoring vegetation systems in the Great Plains with ERTS.

[32] Glenn, E. P., Neale, C. M., Hunsaker, D. J., \& Nagler, P. L. (2011). Vegetation index-based crop coefficients to estimate evapotranspiration by remote sensing in agricultural and natural ecosystems. Hydrological Processes, 25(26), 40504062 .

[33] Rafn, E. B., Contor, B., \& Ames, D. P. (2008). Evaluation of a method for estimating irrigated crop-evapotranspiration coefficients from remotely sensed data in Idaho. Journal of Irrigation and Drainage Engineering, 134(6), 722-729.

[34] Gontia, N. K., \& Tiwari, K. N. (2010). Estimation of crop coefficient and evapotranspiration of wheat (Triticum aestivum) in an irrigation command using remote sensing and GIS. Water resources management, 24(7), 1399-1414.

[35] Wright, J. L. (1982). New evapotranspiration crop coefficients. Proceedings of the American Society of Civil Engineers, Journal of the Irrigation and Drainage Division, 108(IR2), 57-74.

[36] Neale, C. M., Bausch, W. C., \& Heerman, D. (1989). Development of reflectance-based crop coefficients for corn. Trans. ASAE, 32(6), 1891-1899.

[37] Bausch, W. C. (1995). Remote sensing of crop coefficients for improving the irrigation scheduling of corn. Agricultural Water Management, 27(1), 55-68.

[38] Garatuza-Payan, J., Tamayo, A., Watts, C., \& Rodríguez, J. C. (2003). Estimating large area wheat evapotranspiration from remote sensing data. Paper presented at the Geoscience and Remote Sensing Symposium, 2003. IGARSS'03. Proceedings. 2003 IEEE International.

[39] Hunsaker, D. J., Pinter Jr, P. J., Barnes, E. M., \& Kimball, B. A. (2003). Estimating cotton evapotranspiration crop coefficients with a multispectral vegetation index. Irrigation Science, 22(2), 95-104.

[40] Hunsaker, D. J., Pinter, P. J., \& Kimball, B. A. (2005). Wheat basal crop coefficients determined by normalized difference vegetation index. Irrigation Science, 24(1), 1-14.
[41] Duchemin, B., Hadria, R., Erraki, S., Boulet, G., Maisongrande, P., Chehbouni, A.,... Kharrou, M. (2006). Monitoring wheat phenology and irrigation in Central Morocco: On the use of relationships between evapotranspiration, crops coefficients, leaf area index and remotely-sensed vegetation indices. Agricultural Water Management, 79(1), 1-27.

[42] Jayanthi, H., Neale, C. M., \& Wright, J. L. (2007). Development and validation of canopy reflectance-based crop coefficient for potato. Agricultural Water Management, 88(1), 235-246.

[43] Trout, T. J., Johnson, L. F., \& Gartung, J. (2008). Remote sensing of canopy cover in horticultural crops. HortScience, 43(2), 333-337.

[44] González-Dugo, M., \& Mateos, L. (2008). Spectral vegetation indices for benchmarking water productivity of irrigated cotton and sugarbeet crops. Agricultural Water Management, 95(1), 48-58.

[45] Campos, I., Neale, C. M., Calera, A., Balbontín, C., \& González-Piqueras, J. (2010). Assessing satellite-based basal crop coefficients for irrigated grapes (Vitis vinifera L.). Agricultural Water Management, 98(1), 45-54.

[46] Er-Raki, S., Rodriguez, J., Garatuza-Payan, J., Watts, C., \& Chehbouni, A. (2013). Determination of crop evapotranspiration of table grapes in a semi-arid region of Northwest Mexico using multi-spectral vegetation index. Agricultural Water Management, 122, 12-19.

[47] Pôças, I., Paço, T. A., Paredes, P., Cunha, M., \& Pereira, L. S. (2015). Estimation of actual crop coefficients using remotely sensed vegetation indices and soil water balance modelled data. Remote Sensing, 7(3), 2373-2400.

[48] Reyes-Gonzalez, A., Hay, C., Kjaersgaard, J., \& Neale, C. (2015). Use of Remote Sensing to Generate Crop Coefficient and Estimate Actual Crop Evapotranspiration. Paper presented at the 2015 ASABE Annual International Meeting.

[49] Reyes-González, A., Trooien, T., Kjaersgaard, J., Hay, C., \& Reta-Sánchez, D. G. (2016). Development of Crop Coefficients Using Remote Sensing-Based Vegetation Index and Growing Degree Days. Paper presented at the 2016 ASABE Annual International Meeting.

[50] Neale, C. M., Jayanthi, H., \& Wright, J. L. (2005). Irrigation water management using high resolution airborne remote sensing. Irrigation and Drainage Systems, 19(3), 321-336.

[51] Barbagallo, S., Consoli, S., \& Russo, A. (2009). A one-layer satellite surface energy balance for estimating evapotranspiration rates and crop water stress indexes. Sensors, 9(1), 1-21.

[52] Yebra, M., Van Dijk, A., Leuning, R., Huete, A., \& Guerschman, J. P. (2013). Evaluation of optical remote sensing to estimate actual evapotranspiration and canopy conductance. Remote Sensing of Environment, 129, 250-261.

[53] Morton, C. G., Huntington, J. L., Pohll, G. M., Allen, R. G., McGwire, K. C., \& Bassett, S. D. (2013). Assessing calibration uncertainty and automation for estimating evapotranspiration from agricultural areas using METRIC. JAWRA Journal of the American Water Resources Association, 49(3), 549-562. 
[54] Kjaersgaard, J., \& Allen, R. (2010). Remote sensing technology to produce consumptive water use maps for the Nebraska Panhandle. Final completion report submitted to the University of Nebraska, 60.

[55] Reyes-Gonzalez, A., Kjaersgaard, J., Trooien, T., Hay, C. and Ahiablame, L. (2017). Comparative analysis of METRIC model and atmometer methods for estimating actual evapotranspiration, International Journal of Agronomy, (2017), 1-16.

[56] Allen, R., Trezza, R., Tasumi, M., \& Kjaersgaard, J. (2014). METRIC: Mapping Evapotranspiration at High Resolution Using Internalized Calibration Applications Manual for Landsat Satellite Imagery., V 3.0, 279.
[57] Bausch, W. C. (1993). Soil background effects on reflectancebased crop coefficients for corn. Remote Sensing of Environment, 46(2), 213-222.

[58] Bannari, A., Morin, D., Bonn, F., \& Huete, A. (1995). A review of vegetation indices. Remote sensing reviews, 13(1-2), 95-120.

[59] Anderson, M. C., Allen, R. G., Morse, A., \& Kustas, W. P. (2012). Use of Landsat thermal imagery in monitoring evapotranspiration and managing water resources. Remote Sensing of Environment, 122, 50-65. doi:http://dx.doi.org/10.1016/j.rse.2011.08.025. 